\title{
KUALITAS PELAYANAN DAN HARGA TERHADAP LOYALITAS PELANGGAN PERUSAHAAN JASA ANGKUTAN BARANG
}

\author{
* Prima Widiyanto ${ }^{1}$, Firda Aranza ${ }^{2}$, M. Arif Hernawan ${ }^{3}$ \\ ${ }^{1,2} 3$ Institut Transportasi dan Logistik Trisakti, Jakarta, Indonesia
}

\author{
*Email Korespondensi: \\ primawidiyanto@yahoo.com
}

\section{ARTIKEL INFORMASI}

Diterima:

25 Juni 2021

Direvisi:

12 Juli 2021

Dipublikasi:

22 Juli 2021

\begin{abstract}
ABSTRAK
Tujuan kajian ini untuk menganalisis kualitas pelayanan, harga dan loyalitas pelanggan, serta menguji pengaruh variable kualitas pelayanan dan harga terhadap loyalitas pelanggan PT. Ridho Makmur Sentosa di Jakarta Timur. Jenis penelitian Deskriptif kuantitatif, teknik pengambilan sampel menggunakan sampel jenuh, pengumpulan data melalui kuesioner secara online kepada 37 pelanggan dari PT. Ridho Makmur. Teknik Analisa data menggunakan metode analisis regresi linear berganda, uji koefisien determinasi, uji korelasi berganda, uji T, dan uji F. Hasil kajian menunjukkan bahwa terdapat pengaruh antara Kualitas Pelayanan (X1) dan Harga (X2) terhadap Loyalitas Pelanggan (Y) PT. Ridho Makmur Sentosa dimana Y = -2.259 + 0.909X1+0.034X2 memiliki $\mathrm{R}=0,735$ mempunyai pengaruh yang kuat dan positif antara variabel $\mathrm{X} 1$ dan $\mathrm{X} 2$ terhadap $\mathrm{Y}$.
\end{abstract}

Kata Kunci: Kualitas Pelayanan, Harga, Loyalitas Pelanggan

\section{PENDAHULUAN}

Perkembangan dunia bisnis yang sangat pesat telah berdampak pada semakin banyaknya unit usaha baru yang dirintis masyarakat baik yang berskala kecil, menengah maupun berskala besar. Fenomena tersebut diikuti dengan pesatnya perkembangan perusahaan penyedia jasa pengiriman barang. Keberadaan penyedia jasa kurir mampu menunjang kebutuhan para pelaku bisnis karena dapat mengirimkan barang kepada pelanggan, baik yang berada di dekat lokasi usaha maupun yang berada jauh di luar dari daerah operasional perusahaan tersebut, sehingga dapat memperluas cakupan pasar yang secara otomatis akan meningkatkan keuntungan dari perusahaan.

Salah satu perusahaan penyedia jasa pengiriman barang adalah PT. Ridho Makmur Sentosa. Perusahaan ini menyediakan jasa angkutan barang dengan muatan minimal 1 Ton. Berbeda dengan perusahaan angkutan jasa sekelas TIKI, 23 JNE, POS yang dapat mengirimkan barang berdimensi kecil dan berat yang tidak mencapai $1 \mathrm{~kg}$. Produk layanan yang disediakan oleh PT. Ridho Makmur Sentosa adalah trucking, pengiriman kargo internasional, pengiriman kargo domestic, jasa ekspor - impor, pengepakan dan pergudangan, LCT (Landing Craft Tank). Perusahaan ini tidak hanya menyediakan pengiriman barang via darat, melainkan udara serta laut. Walaupun selama ini harga yang ditawarkan oleh Perusahaan cukup bersaing dibandingkan 
dengan yang ditawarkan oleh Perusahaan pesaing dan juga pelayanan yang diberikan, berupa layanan pelanggan untuk complain dan monitoring serta dalam proses mengirimkan barang jarang sekali dalam satu pengirimannya menangani lebih dari satu jenis barang namun tidak dapat menjamin loyalitas pelanggan kepada Perusahaan. Dari Hasil survey menunjukkan bahwa loyalitas pelanggan pada Perusahaan cenderung menurun setiap tahunnya. Dari hasil temuan data ditemukan berdasarkan lamanya kerjasama yang terjalin antara pelanggan dengan Perusahaan berkisar antara 1 sd 5 tahun. Sebagaimana tergambar pada gambar berikut ini :

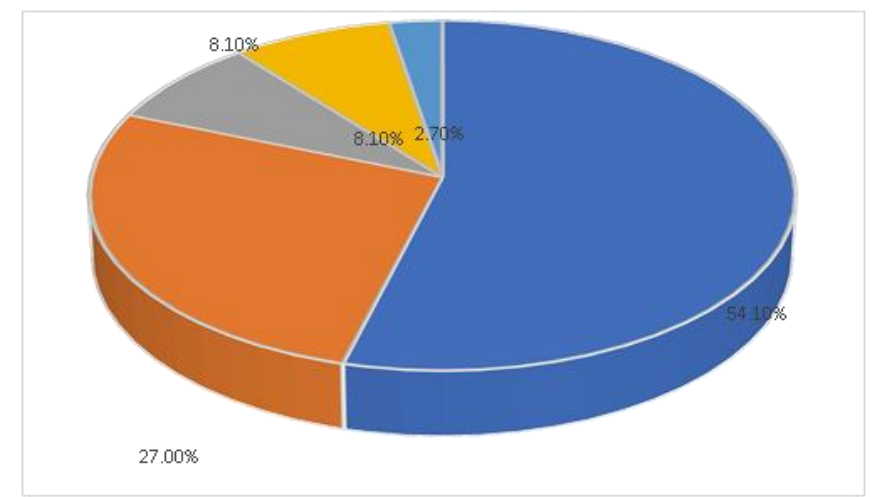

Gambar 1 Data Pelanggan berdasarkan lamanya Kerjasama dengan PT. Ridho Makmur Sentosa

Dari gambar diatas dapat dijelaskan bahwa pelanggan yang bekerjasama dengan perusahaan berdasarkan tahun bekerjasama sbb : 1 tahun sebanyak 20 Perusahaan (warna biru pada diagram), 2 tahun sebanyak 10 pelanggan (warna orange), 3 tahun sebanyak 3 perusahaan (kuning) 4 tahun sebanyak 3 perusahaan (warna abu2) sedangkan yang bekerjasama selama 5 tahun adalah 1 pelanggan (biru muda), artinya loyalitas pelanggan semakin lama semakin berkurang terhadap Perusahaan. Sehingga dapat diartikan bahwa pelayanan dan harga yang selama ini diberikan sangat berpengaruh terhadap loyalitas pelanggan kepada Perusahaan. Melihat dari data diatas terlihat bahwa Loyalitas pelanggan tertinggi ada pada usia Kerjasama 1 tahun, sedangkan terendah ada pada usia Kerjasama 5 tahun yang berarti terdapat kecenderungan penurunan Loyalitas pelanggan, oleh karenanya perlu untuk diketahui bagaimana pengaruh kualitas pelayanan dan Harga baik secara parsial maupun Bersama sama terhadap Loyalitas Pelanggan Perusahaan.

\section{KAJIAN PUSTAKA}

Sebagaimana yang dikemukakan oleh (Sirhan Fikri, Wahyu Wiyani, 2016) bahwa Kualitas pelayanan berpengaruh signifikan terhadap kepuasan. Hal ini menunjukkan bahwa penilaian didasarkan pada selisih atau perbedaan antara yang ideal dengan yang aktual, jika nilai yang ideal dipersepsikan dengan yang dialami adalah sama maka pelanggan akan merasa puas, bila terjadi perbedaan antara yang ideal dipersepsikan oleh pelanggan dan yang dialami maka dapat menimbulkan ketidakpuasan pelanggan. Jadi kepuasan dapat dirasakan oleh pelanggan melalui pengukuran perbedaan antara apa yang diharapkan pelanggan dengan apa yang diterima pelanggan dari pihak penyedia jasa, sebagaimana pandangan Bitner dan Zeithaml (2003) dimana kepuasan merupakan evaluasi pelanggan atas suatu produk atau jasa yang sesuai dengan harapan dan kebutuhan.

Sebagaimana yang disampaikan oleh (Kotler , P., \& Amstrong, 2001) harga adalah satu-satunya elemen bauran pemasaran yang menghasilkan pendapatan. Harga adalah juga merupakan salah satu elemen yang paling dapat dikatakan fleksible dari bauran pemasaran. Sedangkan menurut (Umami et al., 2019) sebuah penyedia layanan dituntut untuk memberikan suatu produk atau jasa dengan kualitas yang baik, baik dalam segi kualitas produk, kualitas pelayanan ataupun dapat memberikan harga produk atau jasa yang lebih terjangkau, sehingga konsumen akan merasa kebutuhannya terpenuhi serta akan menciptakan sebuah kepuasan dari dalam diri konsumen. Sedangkan menurut (Riska Arisandi, 2018) selain kualitas pelayanan, keunggulan bersaing sebuah perusahaan produk atau jasa dapat dilihat juga dari penetapan harga oleh perusahaan. Harga adalah salah satu faktor penting yang mempengaruhi konsumen dalam melakukan pembelian suatu produk atau jasa. 
Kualitas pelayanan yang diberikan pada sebuah perusahaan penyedia jasa atau barang juga dapat mempengaruhi kepuasan pelanggan. jika kualitas pelayanan yang diberikan sebuah perusahaan kepada pelanggannya baik dan meninggalkan rasa senang kepada pengguna atau pelanggan yang menggunakan jasa dari perusahaan tersebut, maka akan menimbulkan kepuasan pelanggan yang secara tidak langsung muncul bersama loyalitas pelanggan.

Loyalitas merupakan gabungan dari proses intelektual dan emosional antara pelanggan dan perusahaan. Akibatnya loyalitas tidak dapat dipaksakan, meskipun loyalitas dapat diukur dan dikelola (Rangkuti, 2003:3). Loyalitas pelanggan dapat ditunjukkan dalam bentuk pembelian ulang terhadap suatu produk atau jasa yang ditawarkan perusahaan, semakin banyak pelanggan yang melakukan pembelian ulang akan memperbesar laba perusahaan Menjaga loyalitas pelanggan bukan pekerjaan mudah bagi produsen untuk terus dipertahankan, salah satu kunci untuk dapat terus mempertahankan sikap loyal dari pelanggan agar dapat tetap bersaing adalah perusahaan harus mampu memberikan kepuasan pelanggan secara berkelanjutan.(Riska Arisandi, 2018).

\section{METODE}

Penelitian ini menggunakan metode kuantitatif, lokasi penelitian di PT. Ridho Makmur Sentosa di Jakarta Timur, Waktu penelitian adalah pada rentang bulan oktober sampai dengan Desember 2019. Populasi pada penelitian ini adalah pengguna jasa PT. Ridho Makmur Sentosa yang berjumlah 37 perusahaan, sedangkan sample yang dipakai adalah sebanyak 37 dengan menggunakan sample jenuh dimana semua anggota populasi diambil sebagai sample penelitian. Untuk variable yang diteliti adalah Variable bebas diwakili oleh Kualitas Pelayanan (x1), Harga (x2) dan variable terikat yaitu Loyalitas pelanggan (Y). Pengumpulan data menggunakan angket yang disebarkan melalui media social (google form) dan pengukuran melalui skala likert. Teknik Analisa data menggunakan Analisis Regresi Linear berganda, Analisis Koefisien Determinasi, uji korelasi berganda. Untuk menguji hipotesis digunakan Uji T dan Uji F.

Kualitas pelayanan dimaknai sebagai sebuah tingkat pelayanan yang dapat menghasilkan kepuasan yang tinggi dan akan terjadi pembelian berulang. Dalam penelitian ini diartikan bukti Fisik, keandalan, daya tanggap, jaminan dan kepastian, dan empati, kemudian variable Harga yaitu Nilai uang yang harus dibayarkan oleh konsumen kepada penjual atas barang atau jasa yag dibelinya untuk mendapatkan manfaatnya. Dalam penelitian ini, indikator yang dipakai adalah : keterjangkauan harga, kesesuaian harga dengan kualitas produk, daya saing harga, kesesuaian harga dengan manfaat, sedangkan untuk Variable Loyalitas Pelanggan (Y) adalah sebuah sikap yang menjadi dorongan perilaku untuk melakukan pembelian produk ataupun jasa dari suatu perusahaan yang menyertakan aspek perasaan didalamnya, khususnya yang melakukan pembelian secara berulang kali dengan konsistensi yang tinggi. Pelanggan juga mempunyai komitmen dan sikap positif terhadap perusahaan tersebut, indikator yang digunakan adalah melakukan pembelian secara teratur, membeli diluar lini produk, merekomendasikan produk atau juga jasa kepada orang lain Menunjukkan kekebalan dari daya tarik produk atau juga jasa sejenis Atau dengan bahasa lain ini tidak mudah dipengaruhi oleh daya tarik produk pesaing.

\section{HASIL DAN PEMBAHASAN}

\section{Analisis Pengaruh Kualitas Pelayanan (x1) terhadapLoyalitas Pelanggan (Y)}

a. Analisis Regresi Linear Sederhana

Hipotesis pertama menyatakan bahwa terdapat pengaruh antara Kualitas pelayanan (X1) terhadap Loyalitas Pelanggan (Y), untuk menguji hipotesis tersebut digunakan Analisis regresi linier sederhana 


\section{Tabel 1 Persamaan Regresi Sederhana Variabel Kualitas Pelayanan (X1) Terhadap Loyalitas Pelanggan (Y)}

\begin{tabular}{|c|c|c|c|c|c|c|}
\hline \multirow[b]{2}{*}{ Model } & & \multicolumn{2}{|c|}{ Unstandardized Coefficients } & \multirow{2}{*}{$\begin{array}{c}\text { Standardized } \\
\text { Coefficients } \\
\text { Beta }\end{array}$} & \multirow[b]{2}{*}{$\mathrm{t}$} & \multirow[b]{2}{*}{ Sig. } \\
\hline & & B & Std. Error & & & \\
\hline \multirow[t]{2}{*}{1} & (Constant) & .642 & 2.983 & & .215 & .831 \\
\hline & Total_X1 & .412 & .100 & .572 & 4.124 & .000 \\
\hline
\end{tabular}

a. Dependent Variable: Total_Y

Sumber : Data diolah SPSS versi 25

Berdasarkan perhitungan menggunakan SPSS 25 pada tabel di atas diketahui nilai a (constant) sebesar 0,642 sedangkan Kualitas Pelayanan (b / koefisien regresi) sebesar 0,412. Maka dapat dibuat persamaan regresi sederhana sebagai berikut:

$$
\begin{aligned}
& Y=\mathbf{a}+\mathbf{b X 1}, \\
& Y=0,642+0,412 X 1
\end{aligned}
$$

dapat diartikan bahwa nilai konsisten variabel kualitas pelayanan adalah 0,642, sedangkan Koefisien regresi $\mathrm{X}$ sebesar 0,412 menyatakan bahwa setiap penambahan satu satuan Kualitas Pelayanan, maka nilai Kepuasan pengguna jasa bertambah sebesar 0.412. Koefisien regresi tersebut bernilai positif, sehingga dapat dikatakan bahwa arah pengaruh variabel X1 terhadap $\mathrm{Y}$ adalah positif.

b. Koefisien korelasi sederhana

\section{Tabel 2 Hasil Analisis Korelasi Sederhana

\begin{tabular}{|c|c|c|c|}
\hline & & Total_X1 & Total_Y \\
\hline \multirow[t]{3}{*}{ Total_X1 } & Pearson Correlation & 1 & $.572^{* *}$ \\
\hline & Sig. (2-tailed) & & .000 \\
\hline & $\mathrm{N}$ & 37 & 37 \\
\hline \multirow[t]{3}{*}{ Total_Y } & Pearson Correlation & $.572 *$ & 1 \\
\hline & Sig. (2-tailed) & .000 & \\
\hline & $\mathrm{N}$ & 37 & 37 \\
\hline
\end{tabular} Correlations}

**. Correlation is significant at the 0.01 level (2-tailed).

Sumber : Data diolah SPSS versi 25

Berdasarkan hasil analisis korelasi sederhana diatas dapat diketahui nilai koefisien korelasi sebesar 0,72 dengan nilai signifikansi 0,000. Maka dapat disimpulkan bahwa variabel Kualitas Pelayanan dan Loyalitas Pelanggan memiliki arah hubungan yang positif atau semakin tinggi Kualitas Pelayanan maka semakin tinggi Loyalitas Pelanggan.

c. Koefisien Determinasi 
Tabel 3 Hasil Analisis Koefisien Determnasi (X1)

Model Summary

\begin{tabular}{ccccc}
\hline Model & $\mathrm{R}$ & R Square & $\begin{array}{c}\text { Adjusted } \mathrm{R} \\
\text { Square }\end{array}$ & $\begin{array}{c}\text { Std. Error of the } \\
\text { Estimate }\end{array}$ \\
\hline & $.572^{\mathrm{a}}$ & .327 & .308 & 2.41374
\end{tabular}

a. Predictors: (Constant), Total_X1

Sumber : Data diolah penulis menggunakan SPSS versi 25

Berdasarkan tabel diatas dapat diketahui nilai koefisien korelasi sebesar 0,572 dan nilai koefisien determinasi nya sebesar 0,327 atau 32,7\%. Dari perhitungan koefisien determinasi diatas maka dapat diperoleh besarnya nilai kontribusi dari pengaruh Kualitas Pelayanan (X1) terhadap Loyalitas Pelanggan (Y) adalah sebesar 32,7 \% dan sisanya 67,3\% merupakan faktor lain.

d. Uji t

Dilakukan untuk menguji hipotesis atau dugaan adanya pengaruh antara masing-masing variabel dimana variabel Kualitas Pelayanan (X1) memberikan pengaruh terhadap variabel Loyalitas Pelalanggan (Y). Dalam penelitian ini penulis menggunakan uji hipotesis dengan tingkat signifikansi sebesar 5\% atau $\alpha=0,05$ Dengan $\mathrm{df}=\mathrm{n}-2$.

Tabel 4 Hasil Uji Signifikansi Parsial Uji T)

\begin{tabular}{|c|c|c|c|c|c|}
\hline \multicolumn{3}{|c|}{ Unstandardized Coefficients } & \multirow{2}{*}{$\begin{array}{c}\text { Standardized } \\
\text { Coefficients } \\
\text { Beta }\end{array}$} & \multirow[b]{2}{*}{$\mathrm{t}$} & \multirow[b]{2}{*}{ Sig } \\
\hline Model & B & Std. Error & & & \\
\hline (Constant) & .642 & 2.983 & & .215 & .831 \\
\hline Total_X1 & .412 & .100 & .572 & 4.124 & .000 \\
\hline
\end{tabular}

a. Dependent Variable: Total_Y

Sumber : data diolah oleh penulis menggunakan SPSS 25

Berdasarkan tabel diatas dapat diketahui nilai Signifikansi untuk pengaruh variabel kualitas Pelayanan (X1) terhadap Loyalitas pelanggan (Y) sebesar $0,000<0,05$ dan nilai $t$ hitung sebesar 4.124. Setelah nilai thitung diketahui maka dapat di cari nilai $t$ tabel dengan menggunakan persamaan sebagai berikut :Taraf nyata $(\alpha)=0,05$, derajat kebebasan (df) sebesar $\mathrm{n}-2=37-2=3$. Dari data tersebut maka dapat diperoleh nilai t tabel sebesar 1.69 yang berati $t$ hitung $>t_{\text {tabel }}(4.124>1,69)$ dari hasil tersebut membuktikan maka HO ditolak dan Ha diterima yang memiliki arti bahwa variabel Kualitas Pelayanan (X1) memberikan pengaruh yang positif dan signfikan terhadap variabel Loyalitas Pelanggan(Y).

\section{Analisis Pengaruh Harga (X2) terhadap Loyalitas Pelanggan (Y)}

Hipotesis kedua menyatakan bahwa terdapat Pengaruh Harga (x2) terhadap Loyalitas pelanggan (Y). Dari hasil pengolahan diperoleh sbb :

\section{Tabel 5 Persamaan Regresi Sederhana Variabel Harga (X2) Terhadap Loyalitas Pelanggan (Y)}


Coefficients $^{\mathrm{a}}$

\begin{tabular}{|c|c|c|c|c|c|}
\hline \multicolumn{3}{|c|}{ Unstandardized Coefficients } & \multirow{2}{*}{$\begin{array}{c}\text { Standardized } \\
\text { Coefficients } \\
\text { Beta }\end{array}$} & \multirow[b]{2}{*}{$\mathrm{t}$} & \multirow[b]{2}{*}{ Sig. } \\
\hline Model & B & Std. Error & & & \\
\hline (Constant) & -1.969 & 2.338 & & -.842 & .405 \\
\hline Total_X2 & .954 & .149 & .734 & 6.395 & .000 \\
\hline
\end{tabular}

a. Dependent Variable: Total_Y

Pada table diatas diketahui nilai a (constant) sebesar -1.969 sedangkan nilai Harga (b / koefisien regresi) sebesar 0.954. Maka dapat dibuat persamaan regresi sederhana sebagai berikut

$\mathrm{Y}=\mathrm{a}+\mathrm{bX} 2$

$\mathrm{Y}=-1.969+0.954 \mathrm{X} 2$

Persamaan diatas dapat diartikan sebagai berikut : Konstanta sebesar -1.969 , mengandung arti bahwa nilai konsisten variabel Kepuasan Pengguna Jasa adalah-1.969. Koefisien regresi $\mathrm{X}$ sebesar 0.954 menyatakan bahwa setiap penambahan satu kesatuan Kualitas Pelayanan, maka nilai Kepuasan Pengguna Jasa bertambah sebesar 0.954. Koefisien regresi tersebut bernilai positif, sehingga dapat dikatakan bahwa arah pengaruh variable Harga (X2) terhadap Loyalitas Pelanggan (Y) adalah positif.

b. Koefisien Korelasi Sederhana Variable Harga (X2) terhadap Loyalitas Pelanggan (Y)

\section{Tabel 6 Hasil Analisis Koefisien Korelasi Sederhana Variabel Harga (X2)} Terhadap Loyalitas Pelanggan (Y)

\begin{tabular}{llll}
\hline Total_Y & & & Total_X2 \\
\hline Total_Y & Pearson Correlation & 1 & $.734^{* *}$ \\
\cline { 2 - 4 } & Sig. (2-tailed) & & .000 \\
\cline { 2 - 4 } & $\mathrm{N}$ & 37 & 37 \\
\hline Total_X2 & Pearson Correlation & $.734^{* *}$ & 1 \\
\cline { 2 - 4 } & Sig. (2-tailed) & .000 & \\
\cline { 2 - 3 } & $\mathrm{N}$ & 37 & 37 \\
\hline
\end{tabular}

**.correlation is significant at the 0.01 level (2-tailed)

Sumber : data diolah penulis menggunakan SPSS 25

Berdasarkan table hasil analisis korelasiederhana diatas dapat diketahui nilai koefisien korelasi sebesar 0,864 dengan nilai signifikansi 0,000. Maka dapat disimpulkan bahwa variable Harga(X2)dan Loyalitas Pelanggan (Y) memiliki arah hubungan yang positif atau semakin tinggi Kualitas pelayanan maka semakin tinggi Harga.

\section{Koefisien determinasi}

Tabel 7 Hasil Analisis Koefisien Determinasi Variabel Harga (X2)

\begin{tabular}{lllll}
\hline Model & $\mathrm{R}$ & $\mathrm{R}$ Square & $\begin{array}{l}\text { Adjusted } \\
\text { Square }\end{array}$ & $\begin{array}{l}\text { RStd. Error of the } \\
\text { Estimate }\end{array}$ \\
\hline & $.734^{\mathrm{a}}$ & .539 & .526 & 1.9982
\end{tabular}

\section{Model Summary}

a. Predictors: (Constant), Total_X2

Sumber : data diolah penulis menggunakan SPSS 25 
Berdasarkan tabel diatas dapat diketahui nilai koefisien korelasi sebesar 0.734 dan nilai koefisien determinasi atau koefisien penentu sebesar 0.539 atau $53.9 \%$. Dari perhitungan koefisien determinasi diatas maka dapat diperoleh besarnya nilai kontribusi dari Harga (X2) terhadap Loyalitas Pelanggan (Y) adalah sebesar 53.9\% dan sisanya 46,1 \% merupakan faktor lain.

\section{c. Uji T}

Tabel 8 Hasil Uji Signifikansi Parsial (Uji t)

\begin{tabular}{cccccc}
\hline \multicolumn{2}{c}{ Unstandardized Coefficients } & \multicolumn{2}{c}{$\begin{array}{c}\text { Standardized } \\
\text { Coefficients } \\
\text { Beta }\end{array}$} & Sig. \\
\hline Model & Std. Error & Beta & & .842 & 405 \\
\hline (Constant) & -1.969 & 2.338 & & .395 & 000 \\
\hline Total_X2 & .954 & .149 & .734 & .39 \\
\hline
\end{tabular}

a. Dependent Variable: Total_Y

Sumber : data diolah oleh penulis menggunakan SPSS 25

Hasil Persamaan Regresi Sederhana Variabel Harga (X2) Terhadap Loyalitas Pelanggan (Y) dapat diketahui nilai Signifikansi untuk pengaruh variabel Harga (X2) terhadap Loyalitas Pelanggan (Y) sebesar $0.000<0.05$ dan nilai t hitung sebesar 6.395. Setelah nilai thitung diketahui maka dapat di cari nilai ttabel dengan menggunakan persamaan sebagai berikut :Taraf nyata $(\alpha)=0.05$ Derajad kebebasan $(\mathrm{df})$ sebesar $\mathrm{n}-2=37-2=35$ Dari data tersebut maka dapat diperoleh nilai $t$ tabel sebesar 1.985 yang berati $t$ hitung $>t$ tabel $\quad(6.395>1,69)$ dari hasil tersebut membuktikan maka HO ditolak dan $\mathrm{Ha}$ diterima yang memiliki arti bahwa variabel Harga (X2) memberikan pengaruh yang positif dan signfikan terhadap variabel Loyalitas Pelanggan (Y).

\section{Analisis Pengaruh Kualitas Pelayanan dan Harga terhadap Loyalitas Pelanggan.}

Tabel 9 Regresi Berganda Kualitas Pelayanan (X1) dan Harga (X2) Terhadap Loyalitas Pelanggan (Y)

\begin{tabular}{|c|c|c|c|c|c|c|}
\hline \multicolumn{4}{|c|}{ Unstandardized Coefficients } & \multirow{2}{*}{$\begin{array}{c}\text { Standardized } \\
\text { Coefficients } \\
\text { Beta }\end{array}$} & \multirow[b]{2}{*}{$t$} & \multirow[b]{2}{*}{ Sig. } \\
\hline Moc & & B & Std. Error & & & \\
\hline \multirow{3}{*}{1} & (Constant) & -2.259 & 2.608 & & -.866 & .392 \\
\hline & Total_X2 & .909 & .229 & .699 & 3.965 & .000 \\
\hline & Total_X1 & .034 & .127 & .047 & .267 & .791 \\
\hline
\end{tabular}

a. Dependent Variable: Total_Y

Sumber : Output data pengolahan SPSS 25

Berdasarkan hasil perhitungan dengan SPSS 25 pada tabel di atas diperoleh nilai a sebesar 2.259; nilai $b_{1}$ sebesar 0,909 ; dan nilai $b_{2}$ sebesar 0,034 untuk persamaan regresi linear berganda sebagai berikut $: Y=-2.259+0.909 X 1+0.034$. Maka angka tersebut menunjukan nilai yang signifikan artinya terdapat pengaruh antara Harga $\left(\mathrm{X}_{2}\right)$ terhadap Kepuasan Pelanggan (Y) sebesar 0,034 dimana jika Harga $\left(\mathrm{X}_{2}\right)$ naik 1 satuan maka akan terjadi peningkatan pada Loyalitas Pelanggan (Y) sebesar 0,034. 


\section{Analisis Korelasi Berganda}

Dilakukan untuk mengukur keeratan hubungan antara variabel Kualitas Pelayanan (X1) dan Harga (X2) dengan Loyalitas Pelanggan (Y) dilakukan uji korelasi, sebagai berikut:

Tabel 10 Rekapitulasi Perhitungan Korelasi Berganda

\begin{tabular}{ccccc}
\hline Model & $\mathrm{R}$ & R Square & $\begin{array}{c}\text { Adjusted R } \\
\text { Square }\end{array}$ & $\begin{array}{c}\text { Std. Error of the } \\
\text { Estimate }\end{array}$ \\
\hline & $.735^{\mathrm{a}}$ & .540 & .513 & 2.02517 \\
\hline
\end{tabular}

a. Predictors: (Constant), Total_X1,Total_X2

Sumber: Output data pengolahan SPSS 25

Pada tabel di atas dari hasil output SPSS 25 dapat dilihat bahwa nilai koefisien korelasi (R) sebesar 0,735. Menurut (Sugiyono, 2007, p. 231), nilai 0.40-0599 di interpretasi Kuat. Sehingga nilai R adalah Sedang, artinya pengaruh antara Kualitas Pelayanan dan Harga Terhadap Loyalitas Pelanggan adalah Sangat Kuat.

\section{Uji F}

Dengan menggunakan signifikasi 5\% atau $(0,05)$ dan pengujian dua sisi maka signifikasi $0,05: 2=0,025$, dapat dilihat Ftabel sebesar 3.09. Berdasarkan hasil dalam perhitungan tersebut maka dapat disimpulkan bahwa nilai Fhitung > Ftabel $(19.434>3.28)$ atau $0,000<0,05$ sehingga H0 ditolak dan Ha diterima, artinya variabel Kualitas Pelayanan (X1) dan Harga (X2) secara global mempunyai pengaruh yang signifikan terhadap Loyalitas Pelanggan (Y).

\section{Koefisien Determinasi}

Berdasarkan diatas dapat diketahui nilai koefisien korelasi sebesar 0.735 dan nilai koefisien determinasi atau koefisien penentu sebesar 0.540 atau $54 \%$. Dari perhitungan koefisien determinasi diatas maka dapat diperoleh besarnya nilai kontribusi dari pengaruh Kualitas Pelayanan(X1) dan Harga(X2) terhadap Loyalitas Pelanggan (Y) adalah sebesar 54\% dan sisanya $46 \%$ merupakan faktor lain.

\section{Hasil uji hipotesis}

1. Kualitas Pelayanan (X1) Terhadap Loyalitas Pelanggan (Y)

Hasil penelitian ini menunjukkan bahwa secara parsial terdapat pengaruh signifikan terhadap Kualitas Pelayanan terhadap Loyalitas Pelanggan pada PT. Ridho Makmur Sentosa. Persamaan variabel Kualitas Pelayanan dengan Loyalitas Pelanggan yaitu $\mathrm{Y}=0,642+$ 0,412X1 dengan nilai kontribusi pengaruh variabel sebesar 32,7\%. Hasil ini diterima dari responden yang telah menjawab pertanyaan melalui kueisioner penelitian ini yang menghasilkan Kualitas Pelayanan menunjukkan nilai t hitung sebesar 4.124 dengan taraf signifikan sebesar 0,000 lebih kecil dari 0,05 yang berarti bahwa dalam penelitian ini Kualitas Pelayanan berdeterminasi secara signifikan terhadap Loyalitas Pelanggan pada PT. Ridho Makmur Sentosa.

2. Harga (X2) Terhadap Loyalitas Pelanggan (Y)

Hasil penelitian ini menunjukkan bahwa secara parsial terdapat pengaruh signifikan antara Kualitas pelayanan terhadap Loyalitas Pelanggan pada PT. Ridho Makmur Sentosa. Persamaan variabel kualitas pelayanan dengan Loyalitas Pelanggan yaitu Y $=-1.969+$ $0.954 \mathrm{X} 2$ dengan nilai kontribusi pengaruh variabel sebesar $53.9 \%$ dan 46,1 \% sisanya merupakan faktor lain. Hasil ini diterima dari responden yang telah menjawab pertanyaan melalui kueisioner penelitian ini yang menghasilkan Kualitas Pelayanan menunjukkan nilai t hitung sebesar 6.395 dengan taraf signifikan sebesar 0,000 lebih kecil dari 0,05 yang berarti bahwa dalam penelitian ini Kualitas Pelayanan secara parsial berdeterminasi signifikan terhadap Loyalitas Pelanggan pada PT. Ridho Makmur Sentosa. 
3. Kualitas Pelayanan dan Harga Terhadap Loyalitas Pelanggan Hasil penelitian ini menunjukan bahwa secara simultan terdapat pengaruh positif signifikan antara variabel Kualitas Pelayanan (X1) dan Harga (X2) terhadap Loyalitas Pelanggan (Y) pada PT. Ridho Makmur Sentosa. Persamaan variabel Kualitas Pelayanan dan Harga terhadap Loyalitas Pelanggan yaitu $\mathrm{Y}=-2.259+0.909 \mathrm{X} 1+0.034 \mathrm{X} 2$ dengan nilai kontribusi pengaruh variabel sebesar $54 \%$ dan $46 \%$ sisanya merupakan faktor lain. Hasil ini diterima dari responden yang telah menjawab pertanyaan melalui kueisioner penelitian ini yang menghasilkan nilai Fhitung $19.434>$ Ftabel 3,27 dan signifikan sebesar 0,000 < 0,05 maka HO ditolak dan $\mathrm{Ha}$ diterima. Dilihat dari koefisien korelasi berganda $\mathrm{R}=0,735$ berarti besarnya pengaruh Kualitas Pelayanan (X1) dan Harga (X2) terhadap Loyalitas Pelanggan (Y) pada PT. Ridho Makmur Sentosa adalah 0,735 yang berarti mempunyai pengaruh yang kuat, searah positif.

\section{KESIMPLAN DAN SARAN}

Berdasarkan hasil penelitian dan pembahasan yang telah dilakukan, dapat disimpulkan bahwa : variabel Kualitas Pelayanan termasuk dalam kategori baik dengan rata rata responden sebesar 4,23. Hal ini menunjukan Kualitas Pelayanan sudah dapat berjalan dengan baik dalam mendukung kegiatan pelayanan, Variabel X2 Harga termasuk dalam kategori cukup baik dengan nilai rata rata sebesar 3,85. Hal ini menunjukan Harga sudah dapat berjalan dengan baik dalam mendukung penjualan jasa, Variabel Y Loyalitas Pelanggan variabel Loyalitas Pelanggan termasuk dalam kategori cukup baik dengan nilai rata - rata sebesar 3,21. Hal ini menunjukan Loyalitas Pelanggan sudah dapat dirasakan oleh pelanggan.

\section{Daftar Pustaka}

Kotler, P., \& Amstrong, G. (2001). Prinsip Prinsip Pemasaran. erlangga.

Riska Arisandi, N. (2018). Pengaruh Kualitas Pelayanan Dan Harga Terhadap Loyalitas Pelanggan Melalui Kepuasan Pelanggan Toko Buku Toga Mas Semarang. Jurnal Administrasi Bisnis Departemen, 1(1), 1-8. http://dx.doi.org/10.1016/j.cirp.2016.06.001\%0Ahttp://dx.doi.org/10.1016/j.powtec.2016.12.055\%0Ahttps ://doi.org/10.1016/j.ijfatigue.2019.02.006\%0Ahttps://doi.org/10.1016/j.matlet.2019.04.024\%0Ahttps://doi .org/10.1016/j.matlet.2019.127252\%0Ahttp://dx.doi.o

Sirhan Fikri, Wahyu Wiyani, A. S. (2016). Pengaruh Kualitas Pelayanan Terhadap Kepuasan Dan Loyalitas Mahasiswa (Studi pada Mahasiswa Strata I Fakultas Ilmu Sosial dan Ilmu PolitikUniversitas Merdeka Malang) Sirhan Fikri, Wahyu Wiyani, Agung Suwandaru. Bisnis Dan Manajemen, 3(1), 120-134.

Umami, R., Rizal, A., \& Sumartik, S. (2019). Pengaruh Kualitas Produk, Harga Dan Kualitas Pelayanan Terhadap Kepuasan Konsumen Kedai Warsu Coffe Cafe. Equilibrium: Jurnal Ekonomi-ManajemenAkuntansi, 15(2), 250. https://doi.org/10.30742/equilibrium.v15i2.630 